\title{
Information \& communication technology and true real GDP: economic analysis and findings for selected countries
}

\author{
Paul J. J. Welfens • Jens K. Perret \\ Published online: 13 October 2013 \\ (C) Springer-Verlag Berlin Heidelberg 2013
}

\begin{abstract}
The expansion of information \& communication technology (ICT) is continuing in OECD countries and the world economy - partly due to the ongoing fall of relative ICT prices. The continuing absolute fall of ICT prices and ICT capital prices, respectively, is not adequately considered in the standard analysis of ICT. In the study presented here the ICT investment-GDP ratio is calculated in real terms and it is shown that this ratio is higher (order of magnitude is about 2 percentage points) than the nominal investment-GDP ratio which is misleading the ICT sector, policy makers and society at large. Moreover, we take an innovative look at the digital time budget of private households in selected OECD countries. Assuming that $10 \%$ represents the relevant share of the time budget the digital value-added of private households stands for an unrecorded digital value-added of $2-5 \%$ of gross domestic product; with a share of $20 \%$ of the household's internet time budget devoted to value-added the hidden internet value-added in the US would be in the range of 4.7-10.4\%. Hence the overall understimation of the ICT sector's contribution to GDP is considerable and therefore changes in official statistical analysis and the System of National Accounts are required.
\end{abstract}

Keywords Growth - Investment.Information and communication technology· Internet usage $\cdot$ System of national accounts

\footnotetext{
Acknowledgments We are grateful for the research assistance of Tony Irawan, EIIW/Schumpeter School of Business and Economics at the University of Wuppertal. Comments by participants of the project workshop in Frankfurt (Jean Monnet Project: Digital EU Integration and Globalization) are gratefully acknowledged. The usual disclaimer applies.
}

P. J. J. Welfens $(\bowtie) \cdot J$. K. Perret

European Institute for International Economic Relations (EIIW), University of Wuppertal, Rainer-Gruenter-Str. 21, 42119 Wuppertal, Germany

e-mail: welfens@eiiw.uni-wuppertal.de

URL: www.eiiw.eu

J. K. Perret

e-mail: perret@wiwi.uni-wuppertal.de 


\section{Introduction}

The EU2010 agenda emphasized the importance of information and communication technology (ICT) and the role of digital networking for improving international competitiveness. In the US the government continues to emphasize the role of ICT for economic growth and publications by the World Bank (World 2012) also highlight the critical role of ICT for economic development (Kelly and Minges 2012; Qiang et al. 2012a, b; Yamamichi 2012; Youngman 2010; Sudan et al. 2010; Singh and Raja 2010); this includes digital network expansion projects in Africa and Latin America financed by the World Bank. The adoption of modern ICT in the economy is not possible without some adaptation and learning on the side of firms as well as individuals and it raises the important question of how ICT can be integrated in a basic growth model. A specific trait of the ICT sector is the continuous fall of ICT prices in most OECD countries and indeed worldwide. The implications of this specific trait of ICT are, however, not well understood. For example the fall of ICT investment expenditures relative to the nominal gross domestic product - a phenomenon observed in several OECD countries since about 2005-has been interpreted as indicating a declining role of ICT for economic growth.

As we will show real ICT investment relative to real GDP indicates a different development: this ratio continues to increase and it is indeed this ratio which matters for growth in general and for assessing the economic relevance of ICT.

It is unclear to what extent the ICT investment and ICT output shown in official statistics reflect true value added - the calculation of ICT investment in real terms could be addressed in various ways. A simple approach is to assume that the deflator for ICT investment is the same as for ICT products, a more refined approach used here is to focus on the ICT investment price index which is falling in almost all OECD countries. The implication is that true ICT investment and hence true real GDP is higher than stated in statistics that do not consider adequate price indices for calculating real figures. Moreover, the internet-as an important field of ICT - is a crucial digital element that stands not only for consumption on the side of private households, rather because many individuals use the internet at home and are active as "prosumers" (a hybrid role of consumer and producer) a part of the time budget of private households can even be interpreted as labor input for production. A growing number of old and new services can be availed of via the internet and the creation of certain services relies on the active involvement of digital users - this could even include certain digital entertainment activities in which users of digital networks cooperate in providing joint services to each other. This digital self-service value-added is increasing in many countries of the world.

In the following analysis we highlight standard views on the ICT sector and the official scope of the ICT sector (Section 2); and we look at the importance of ICT investments for growth (Section 3). Moreover, we focus on price level developments of ICT and the crucial implications in selected OECD countries (Section 4); the role of ICT in the economy is much underestimated in official statistics - - our estimate is in the range of $2-5 \%$ where this is split up into an underestimation of real ICT investment and the non-coverage of "internet value-added from households" (Section 5). The policy conclusions are presented in Section (6). 


\section{The ICT sector}

Many authors have found empirical evidence that ICT has an important positive contribution on economic development (Jorgenson and Stiroh 2000; Colecchia and Schreyer 2002; Venturini 2009; Seo et al. 2009). Many approaches have been used in order to analyze the role of ICT sector in the economy. One of them is Input-output analysis. Rohman (2012) analyzed the ICT sectors in European countries by comparing the multiplier effect of the ICT sector over time. He found a decline in the multiplier effect and output of ICT sectors during the period 2000-2005. It is, however, unclear how to interpret this finding: One the one hand, this seems to indicate that the ratio of ICT to GDP has already reached a rather high level so that induced marginal productivity effects in sectors standing for backward linkages and forward linkages are falling over time; an alternative interpretation is that ICT investment has been rather strong and that learning costs - which are rising as a function of the ratio of ICT to GDP — are increasing temporarily.

A useful definition of the ICT sector can be based on the aggregation of 12 out of the 59 sectors in European countries Input-output Table. Heng and Thangavelu (2010) measured the impact of information technology on Singaporean economic growth. They also used a broad definition of the ICT sector (aggregate ICT sector). Some other studies such as Narayana (2005) and Bazzazan (2009) also used input output analysis in order to analyze the ICT issue by using an aggregate ICT sector. Indeed, Bazzazan (2009) calculated normalized backward and forward linkage for 9 ICT sub-sectors in the Iranian economy. However, the approach did not follow the common ICT sector definition and included a non-ICT sector.

By using an I-O table, several indicators can be calculated, namely the output multiplier, income multiplier, backward linkage and forward linkage. These indicators provide valuable information on the importance of the ICT sector in the economy.

A basic issue that we need to address here is the definition of the ICT sector/product. Since 1998, the OECD has been developing an ICT sector/product definition and it has been revised twice. The first ICT definition was based on ISIC Rev. 3 in 1998 and it was followed by the revised ICT sector definition based on ISIC Rev. 3.1 in 2002. The last version is the second ICT sector definition based on ISIC Rev. 4. The resultant detailed definition is presented in Fig. 1. Before we conduct the analysis, we need to define the scope of the sector. If we use the latest I-O Table which follows ISIC Rev. 4 definition, then we should use the second ICT sector definition by OECD (2007). Table 1 shows the detailed ICT sector definition based on 4 digits ISIC Rev. 4 definition.

\section{The importance of ICT investments for economic growth}

Adopting a simple GDP demand side perspective one can focus on the use-side equation ( $\mathrm{Y}$ is real output, $\mathrm{C}$ is consumption, I investment, $\mathrm{G}$ government consumption, $\mathrm{X}_{\text {net }}$ is the current account in real terms):

$$
\mathrm{Y}=\mathrm{C}+\mathrm{I}+\mathrm{G}+\mathrm{X}_{\text {net }}
$$

In the context of this approach every variable can be divided into an ICT related part and a non-ICT part. This holds especially true for investment in ICT. These investments can be made by the public sector or the private sector; however, government will have to provide a clear legal framework for the digital world and ICT investment, respectively. 


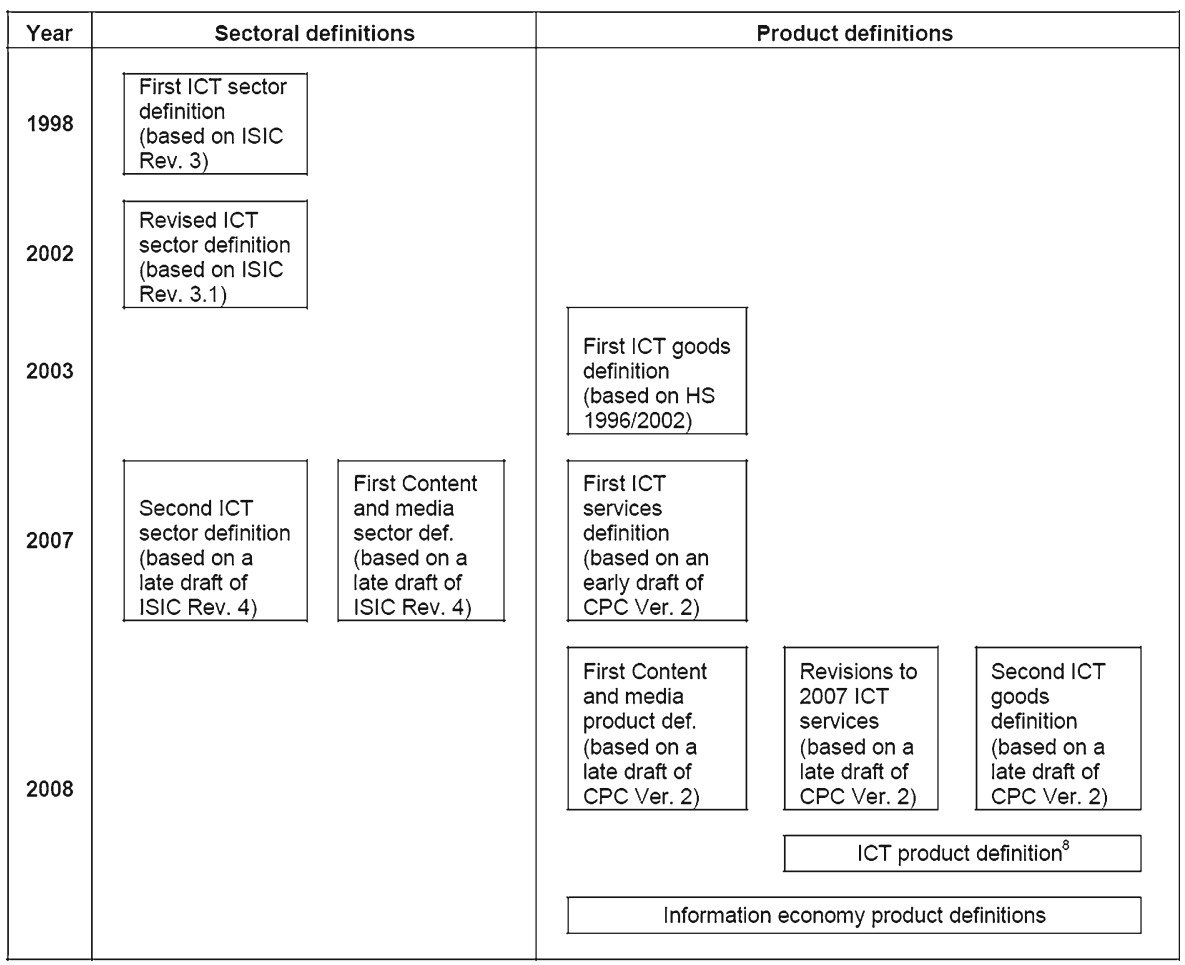

Fig. 1 The definition of ICT sector/products based on OECD (2009)

This includes data protection as well as an adequate definition of universal services. The sectoral split in ICT investment is, however, rather strange in OECD countries. The education sector stands for 5-6\% of GDP in industrialized countries, however, ICT investment is only about $1 \%$ (OECD 2012). The OECD Internet Economy report also reveals some other interesting findings: E.g. $30 \%$ of Canadians found a new job via the internet in 2011, while in Germany and France only about 18 and $15 \%$, respectively, have used the internet for getting a new job - not to mention Greece, Italy and Portugal with even lower figures of $12 \%, 11 \%$ and $11 \%$, respectively (OECD 2012, Fig. 3.19). There is not much doubt that the high share of private universities in the US and Australia should lead to more ICT investment in the education sector in these countries than in most other OECD countries. To the extent that ICT expansion in the education sector reinforces the quality of human capital formation - and assuming that human capital and ICT capital are complementary-increasing ICT investment in higher education will raise the productivity of the higher education sector and also raise the quality of teaching performance as well as research performance in universities. From this perspective the US and Australia - possibly also the UK - have rather favourable perspectives on ICT expansion. This might also hold for Switzerland where there is competition between federally funded excellence universities (ETH Zurich and ETH Lausanne) and regionally funded universities. The decision of states in Germany to abolish modest fees for students - introduced in some states at the beginning of the 21st century - is strange in this respect; digital leadership will be difficult to establish in such a setting. 
Table 1 ICT sector classification based on OECD (2007)

\begin{tabular}{|c|c|}
\hline ISIC rev. 4 code & Name/Definition \\
\hline \multicolumn{2}{|c|}{ ICT manufacturing } \\
\hline 2610 & Manufacture of electronic components and boards \\
\hline 2620 & Manufacture of computers and peripheral equipment \\
\hline 2630 & Manufacture of communication equipment \\
\hline 2640 & Manufacture of consumer electronics \\
\hline 2680 & Manufacture of magnetic and optical media \\
\hline \multicolumn{2}{|c|}{ ICT services (including trade sector) } \\
\hline 4651 & Wholesale of computers, computer peripheral equipment and software \\
\hline 4652 & Wholesale of electronic and telecommunications equipment and parts \\
\hline 5820 & Software publishing \\
\hline 61 & Telecommunications: \\
\hline 6110 & - Wired telecommunications activities \\
\hline 6120 & - Wireless telecommunications activities \\
\hline 6130 & - Satellite telecommunications activities \\
\hline 6190 & - Other telecommunications activities \\
\hline 62 & Computer programming, consultancy and related activities \\
\hline 6201 & - Computer programming activities \\
\hline 6202 & - Computer consultancy and computer facilities management activities \\
\hline 6209 & - Other information technology and computer service activities \\
\hline 631 & Data processing, hosting and related activities; web portals: \\
\hline 6311 & - Data processing, hosting and related activities \\
\hline 6312 & - Web portals \\
\hline 951 & Repair of computers and communication equipment \\
\hline 9511 & - Repair of computers and peripheral equipment \\
\hline 9512 & - Repair of communication equipment \\
\hline
\end{tabular}

Source: OECD 2007

From the supply side one may emphasize that the macroeconomic production function can be written in a simple form as $Y=\mathrm{K}^{\beta}(\mathrm{AL})^{1-\beta}$ where $\mathrm{K}$, A and L stand for capital, knowledge and labor, respectively $(0<\beta<1)$ - to what extent a growing share of ICT capital in $\mathrm{K}$ effectively changes the production function and to what extent ICT expansion stimulates knowledge expansion has to be analysed; this also holds for the role of learning costs in the context of ICT expansion in the economy (see Appendix).

To depict the relationship between ICT investment and output the following figure gives an overview for the selected five countries that have been introduced above. Both variables are given in real values with 1990 as a base year. The choice for 1990 as a base year is argued in more detail in the following section. The following figure shows a steadily increasing real share of ICT investments relative to GDP, implicating that in all countries investment in ICTs has increased in real terms relative to real GDP. In particular it can be seen that while all countries start at relatively the same level over time the share of ICT investment in total GDP in the US has risen much more steeply than in the other four countries (Fig. 2). 


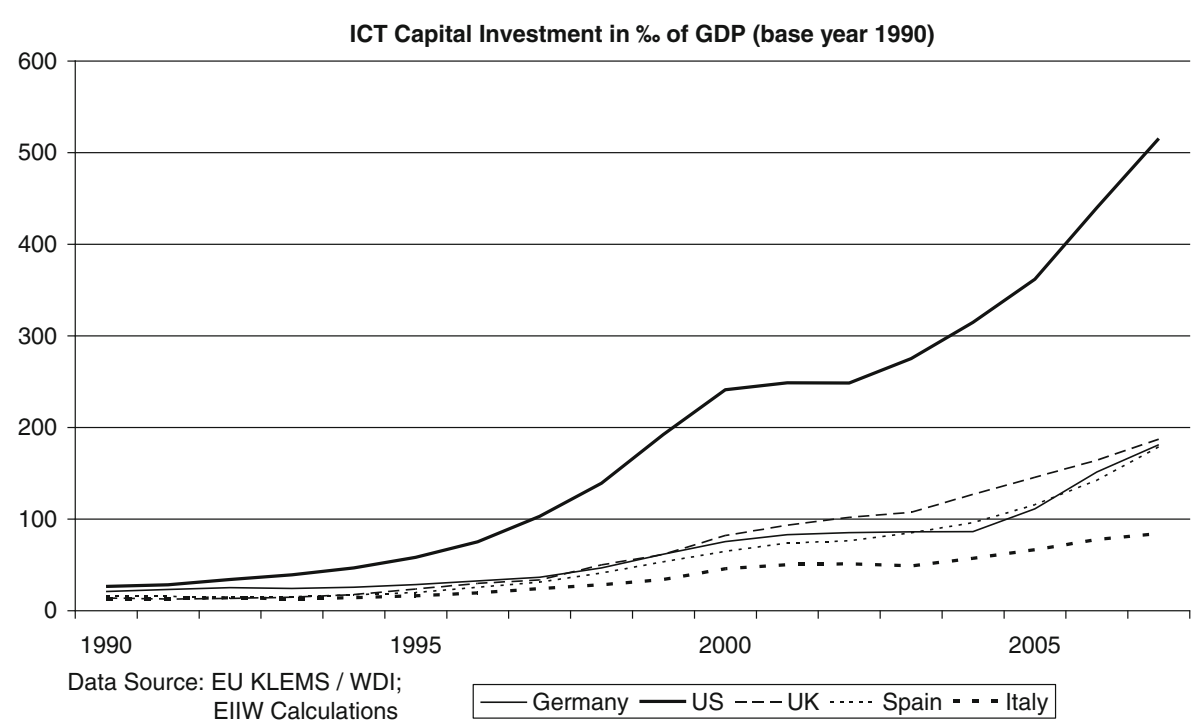

Fig. 2 Real ICT capital investment in \%o of real GDP (base year 1990)

On the other side in Italy the growth has been much more stymied than in the four other countries. The only country that does not keep this development similar to that of the other countries, and thereby holding a similar pattern over time, is Germany. Germany started with the second highest share in the 90s only to be overtaken in the last years of the 1990s by the UK and even, some years later, by Spain. Only in the most recent years has the share of ICTs in Germany risen again, so that in 2007 it lies between the levels of the UK and Spain. The trend though indicates that it has already overtaken the UK in the years after 2007.

In addition to the figure above, setting the stock of ICT investments in relation to GDP per capita it can be shown that there is a stable commonality between an established ICT infrastructure and a high standard of living. Following Moore's Law that the calculation speed of computer chips is doubled every three (previously four) years a time horizon of about 10 years seems plausible to be set as a maximum lifespan of ICT investments. Therefore, the ICT stock of each country is calculated as:

$$
\mathrm{I}_{\mathrm{t}}^{\mathrm{ICT}-\text { stock }}=\sum_{\mathrm{i}=0}^{9} \frac{1}{1+\mathrm{i}} \mathrm{I}_{\mathrm{t}-1}^{\mathrm{ICT}}
$$

The situation for all four countries represented clearly shows a positive relation between income and a modern ICT infrastructure (data for the UK is missing due to insufficient data supply by the World Bank).

The most interesting insight gained is that the relation between income and ICT infrastructure is most pronounced in those countries with a lower overall income as well as a less developed infrastructure. Nevertheless, the apparent correlation might also work in the other direction, namely that a high income leads to higher investments in ICT and therefore a better ICT infrastructure. To clarify this issue one will need more data and it also will be interesting to learn from on-going World Bank projects. It also might be helpful to apply causality tests to the data to get statistical evidence on the direction of causality; the ITU database offers a rich set of ICT data that could be exploited in the future. 
There is an apparent link between GDP per capita and ICT investment, however, this is only one of the crucial aspects of ICT dynamics. Due to the already mentioned characteristic of being a general purpose technology and the trait of ICT investment to generate network effects, ICT investments could have positive external effects on the development of the GDP and the GDP per capita as well; network effects might be relevant here - e.g. if the ICT capital stock of region i is $\mathrm{KICT}_{\mathrm{i}}$ and of region $\mathrm{j} \mathrm{KICT}_{\mathrm{j}}$ the utility of using the regional ICT capital stock in each region is not only a function of the regional ICT capital stock but of ICT capital stock in adjacent regions as well (assuming that interregional and international digital networks exist which are not effectively separated by different languages).

If those spillover effects were to be introduced into a model, Eq. (1) for the GDP would change to (with the positive parameter $\varphi$ standing for the size of the investment spillover effect at the national level):

$$
\begin{aligned}
& \mathrm{Y}_{\mathrm{t}}=\mathrm{C}_{\mathrm{t}}+\mathrm{I}_{\mathrm{t}}^{\text {non-ICT }}+(1+\varphi) \mathrm{I}_{\mathrm{t}}^{\mathrm{ICT}}+\mathrm{G}_{\mathrm{t}}+\mathrm{X}_{\mathrm{t}}^{\text {net }}+\alpha \mathrm{I}_{\mathrm{t}}^{\mathrm{ICT}-\text { stock }} \mathrm{Y}_{\mathrm{t}} \\
& \left(1-\alpha \mathrm{I}_{\mathrm{t}}^{\mathrm{ICT}-\text { stock }}\right) \mathrm{Y}_{\mathrm{t}}=\mathrm{C}_{\mathrm{t}}+\mathrm{I}_{\mathrm{t}}^{\mathrm{non}-\mathrm{ICT}}+(1+\varphi) \mathrm{I}_{\mathrm{t}}^{\mathrm{ICT}}+\mathrm{G}_{\mathrm{t}}+\mathrm{X}_{\mathrm{t}}^{\mathrm{net}} \\
& \mathrm{Y}_{\mathrm{t}}=\frac{\mathrm{C}_{\mathrm{t}}+\mathrm{I}_{\mathrm{t}}^{\text {non-ICT }}+(1+\varphi) \mathrm{I}_{\mathrm{t}}^{\mathrm{ICT}}+\mathrm{G}_{\mathrm{t}}+\mathrm{X}_{\mathrm{t}}^{\text {net }}}{1-\alpha \mathrm{I}_{\mathrm{t}}^{\mathrm{ICT}-\text { stock }}}
\end{aligned}
$$

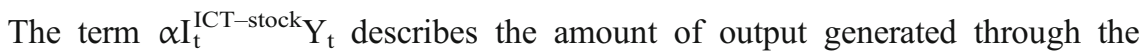
characteristic of ICTs as a general purpose technology where the demand effect of the relevant supply effect is assumed to be a high as the latter. The parameter $\alpha$ gives the magnitude of the influence a rise in the ICT stock has on other industries. It is assumed that the network effects are proportional to the output; if an economy is less developed - as measured by being a lower GDP per capita - it can be assumed that the economy does not have the potential to easily exploit the possibilities a higher stock of ICTs offers. Such a mechanism might be linked to a positive correlation between higher education and per capita income, respectively, and ICT capital.

The parameter $\varphi$ gives the additional value added through network effects the introduction of new technologies, or their adoption, brings. While we will get to this relation in the end of this analysis the main interest at first concerns the development of the term for ICT investment.

Due to a perceived development in international, intertemporal and especially intersectoral price levels (for more details see Fig. 3) it is necessary to avoid comparison problems. Therefore, it is imperative to use real data, not only when describing the development of the ICT investments but also when discussing the effects ICT investments will have on growth. Problems that arise when nominal ICT data is converted to real data are discussed in detail in the following section and the appendix puts the focus in some detail on the considerable differences between nominal ICT investment-GDP ratios and real ICT investment-real GDP ratios; moreover, the appendix also shows data from infratest on the frequency of internet usage; infratest has conducted surveys in various countries (provision of data is gratefully acknowledged). 


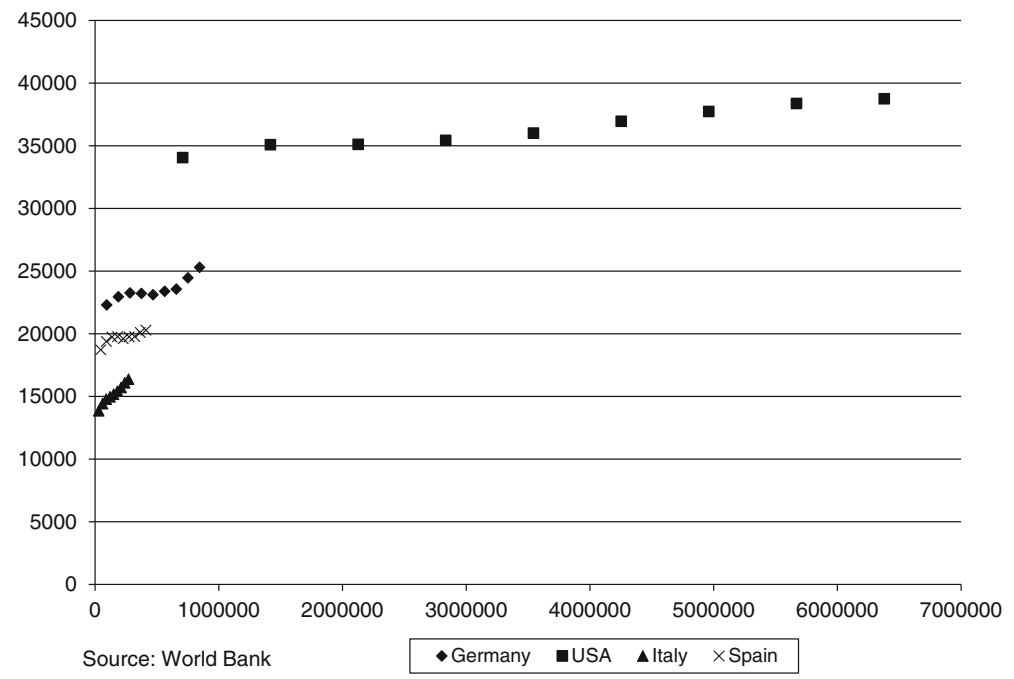

Fig. 3 ICT capital stocks and GDP per capita

\section{Price level developments of ICT}

The following table presents an overview of the development of price levels ( $\left.\mathrm{P}^{\prime}\right)$ of ICT capital investments in selected countries; also indicated is $\mathrm{P}^{\prime} / \mathrm{P}$ ( $\mathrm{P}$ is the GDP inflator). The database used for the preparation of the table as well as the following analysis is the second edition of the EU KLEMS database (EU KLEMS, 2009) on investments in EU as well as selected non-EU countries. Due to the fact that comprehensive data for Germany is only available from the beginning of 1991 onwards 1990 has been chosen as a starting year, though for Germany linear extrapolation has been used to calculate a respective date. Furthermore, the selected time frame has been chosen such that data for the countries considered are fully available. The development of relative prices (with 1995 set at unity) in Germany, the US, the UK, Spain and Italy shows that there are ICT problems in Spain: The decline of the relative price in Spain, in the period 1995-2007, has been much smaller than that in the other countries considered. Lack of competition in Spain, corruption and a relatively large size of the non-tradables sector as well as non-tariff barriers are potential explanations for this finding (Table 2).

With the base year set at 2000 we observe that the relative price decline of ICT products is relatively modest in Spain in the period 2000-2007-considering the ICT price index itself this suggests lack of competition in Spain's ICT sector. It can be seen that in the beginning of the selected time frame the US and Germany have relatively higher price levels than the other three countries; this could be an indicator that in the low price countries only well established technologies were introduced in contrast to the US and Germany where the higher price levels might be an indicator of investments in higher quality technologies in the ICT sector. In the final year of our study, 2007, it can be seen that in all countries the price levels have shrunken in comparison to 1990 as well as to 1995 . Interestingly enough in 2007 the US, UK and Italy have nearly the same price level while Spain has a much higher price level and Germany a much lower one. 
Table 2 ICT price indices with base year 2000 and relative price index (own calculations)

\begin{tabular}{|c|c|c|c|c|c|c|c|c|c|c|}
\hline & \multicolumn{2}{|c|}{ Germany } & \multicolumn{2}{|l|}{ US } & \multicolumn{2}{|l|}{ UK } & \multicolumn{2}{|l|}{ Spain } & \multicolumn{2}{|l|}{ Italy } \\
\hline & $\mathrm{P}^{\prime}$ & $\mathrm{P}^{\prime} / \mathrm{P}$ & $\mathrm{P}^{\prime}$ & $\mathrm{P}^{\prime} / \mathrm{P}$ & $\mathrm{P}^{\prime}$ & $\mathrm{P}^{\prime} / \mathrm{P}$ & $\mathrm{P}^{\prime}$ & $\mathrm{P}^{\prime} / \mathrm{P}$ & $\mathrm{P}^{\prime}$ & $\mathrm{P}^{\prime} / \mathrm{P}$ \\
\hline 1990 & 1.28 & 1.51 & 1.28 & 1.44 & 1.01 & 1.18 & 1.06 & 1.38 & 1.00 & 1.27 \\
\hline 1991 & 1.21 & 1.39 & 1.25 & 1.36 & 1.19 & 1.30 & 1.09 & 1.33 & 1.02 & 1.20 \\
\hline 1992 & 1.51 & 1.25 & 1.16 & 1.24 & 1.08 & 1.15 & 1.07 & 1.22 & 1.01 & 1.14 \\
\hline 1993 & 1.10 & 1.15 & 1.12 & 1.17 & 1.03 & 1.07 & 1.05 & 1.14 & 1.00 & 1.09 \\
\hline 1994 & 1.07 & 1.09 & 1.06 & 1.08 & 1.06 & 1.09 & 1.02 & 1.07 & 1.01 & 1.06 \\
\hline 1995 & 1.00 & 1.00 & 1.00 & 1.00 & 1.00 & 1.00 & 1.00 & 1.00 & 1.00 & 1.00 \\
\hline 1996 & 0.92 & 0.91 & 0.90 & 0.88 & 0.95 & 0.92 & 0.94 & 0.91 & 0.95 & 0.91 \\
\hline 1997 & 0.87 & 0.86 & 0.80 & 0.77 & 0.87 & 0.83 & 0.87 & 0.82 & 0.89 & 0.83 \\
\hline 1998 & 0.76 & 0.75 & 0.69 & 0.66 & 0.75 & 0.70 & 0.79 & 0.73 & 0.79 & 0.72 \\
\hline 1999 & 0.67 & 0.66 & 0.61 & 0.57 & 0.69 & 0.63 & 0.73 & 0.66 & 0.69 & 0.61 \\
\hline 2000 & 0.64 & 0.63 & 0.58 & 0.53 & 0.61 & 0.55 & 0.70 & 0.61 & 0.61 & 0.53 \\
\hline 2001 & 0.58 & 0.57 & 0.53 & 0.48 & 0.52 & 0.46 & 0.65 & 0.54 & 0.56 & 0.48 \\
\hline 2002 & 0.50 & 0.48 & 0.49 & 0.43 & 0.46 & 0.40 & 0.66 & 0.53 & 0.53 & 0.44 \\
\hline 2003 & 0.44 & 0.42 & 0.45 & 0.39 & 0.43 & 0.37 & 0.64 & 0.49 & 0.51 & 0.41 \\
\hline 2004 & 0.43 & 0.41 & 0.43 & 0.36 & 0.39 & 0.32 & 0.63 & 0.46 & 0.46 & 0.36 \\
\hline 2005 & 0.35 & 0.33 & 0.40 & 0.33 & 0.36 & 0.29 & 0.62 & 0.44 & 0.41 & 0.31 \\
\hline 2006 & 0.29 & 0.27 & 0.36 & 0.28 & 0.34 & 0.27 & 0.58 & 0.39 & 0.37 & 0.28 \\
\hline 2007 & 0.25 & 0.23 & 0.34 & 0.26 & 0.33 & 0.25 & 0.55 & 0.36 & 0.34 & 0.25 \\
\hline
\end{tabular}

Source: EU KLEMS

If a simplistic argument is deduced from the data above it would implicate that the quality of technologies that are implemented in 2007 are highest in Spain while Germany introduces mostly outdated, cheap technologies. The dynamics, however, have to be analysed in differentiated way. As an example the developments of the US and the German price levels are plotted against each other. The continuous lines indicate the price levels as an index with the base year 1990 and the dotted lines give the price levels as an index with the base year 2000 .

It is immediately obvious that with the base year 2000 the price levels have shown a divergent development in the years previous to the base year and do so again in the years afterwards. In the other case the development is more or less similar, with only a slight divergence in the years between 1995 and 2003 as well as in the years from 2004 onwards. Though these divergences are less severe than is the case with 2000 used as a base year. The reason for this development is that a divergence of price levels is more pronounced if the price levels are on a different level in the year that is set as a base year. In this context the difference that can be seen for the year 2000 - not only in Fig. 3 but as well in Table 1 - shows that 2000 is not a reasonable choice as a base year (getting from the statistical development back to real economic development, the year 2000 might be a doubtful benchmark year due to the developments that ultimately lead to the Dotcom crisis that was most pronounced in the US, even more than in Germany or the other selected countries). 
In the year 1990 though, the usage of ICTs per se that had not been that established and therefore the investment in respective technologies - at least compared to recent years - had been rather low. In particular the countries observed in this study are most similar in their development in those years, at least considering the available time frame. Therefore, in the following study the base year is 1990 .

Nevertheless, when choosing 1990 the two problems remain that need to be kept in mind when interpreting the resulting data. In 1990 the telecommunication market and thereby large parts of the ICT market at least in Germany, as well as in European and nonEuropean countries like China and India, were still publicly owned or at the least highly regulated so that 1990 might not stand for a sectoral and general equilibrium. Additionally, in 1990 the overall ICT infrastructure in many parts of the industrialized world were still in a modest stage of development (with the possible exception of the Scandinavian countries). The scope for continuous growth was related to GDP per capita growth and product innovations as well as process innovations; the EU orchestrated liberalization of fixed line telecommunications markets in the EU in 1998 - the UK had already opened up in 1984 within a national liberalization approach - is likely to have stimulated innovation dynamics as well as to have facilitated the exploitation of static and dynamic scale economies. One cannot rule out that ICT network effects are observed only once a certain threshold level of digital development of the economy has been achieved.

\section{Analysis of real ICT investment ratios}

Switching from ICT investment price levels to the real investment levels, a rise of the real ICT investment ratio meaning the relation between real ICT investments and real GDP, there can be four possible reasons for a rise. The most obvious reason can be a rise in ICT investments or a fall of the ICT price level, which following the argumentation of the previous section might then lead to the former. On the other hand a rise of the real GDP is possible - either due to a fall of nominal GDP or a rise of the GDP deflator. Nevertheless, the real GDP - though fluctuating according to the business cycle - can be seen as generally rising over time. Therefore a rise in real ICT investment ratios reflects on the one hand the development of ICT investments while on the other hand it reflects the importance of ICT investments for economic growth.

Additionally, an important question in a cross-country analysis is whether the investment ratios converge or diverge. In principle, one reason for convergence can also be found in the price levels and the developments of relative ICT price positions. Convergence can mean either that a country lacking behind has a lot of catching-up in the field ICT infrastructure or the leading country might have reached its maximum development of the ICT infrastructure - which does not necessarily indicate that there is no potential left in its development; however, its development has stagnated at some preliminary steady state. In contrast, if a divergence process is to be observed, it would indicate, that leading countries reinforce their lead, while countries lagging behind only fall back even farther. The following two figures portray the development of ICT investment in the selected countries.

Comparing Figs. 1 and 4 above, the impression is partly given that each figure describes a different set of dynamics concerning Germany and the United States, as in the first figure it seems that there is a convergence in real ICT investments while the second figure suggests a divergence in the levels of real ICT investments. 


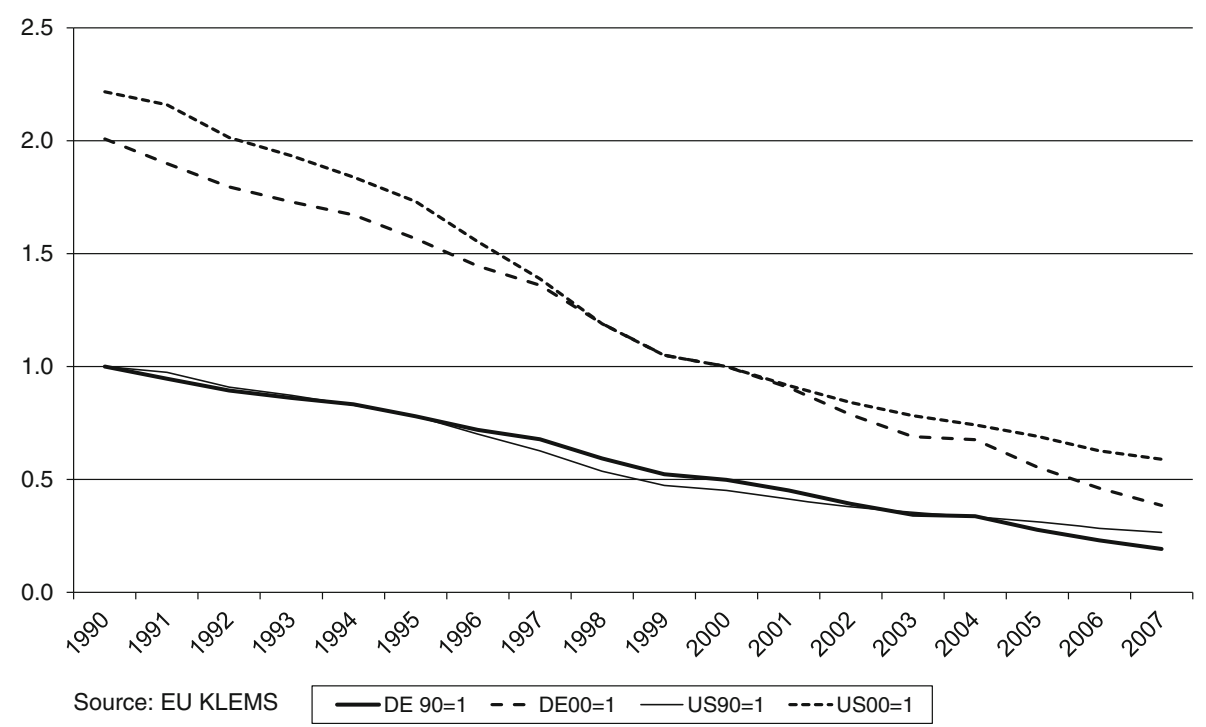

Fig. 4 ICT price levels with different base years (1990 vs. 2000) for the US and Germany

The difference in both figures though lies solely in the different base years for the calculation of real prices. This problem has already been discussed in the preceding section - the Fig. 5 describes the development in an adequate way.

ICT Capital Investment in \%॰ of GDP (base year 2000)

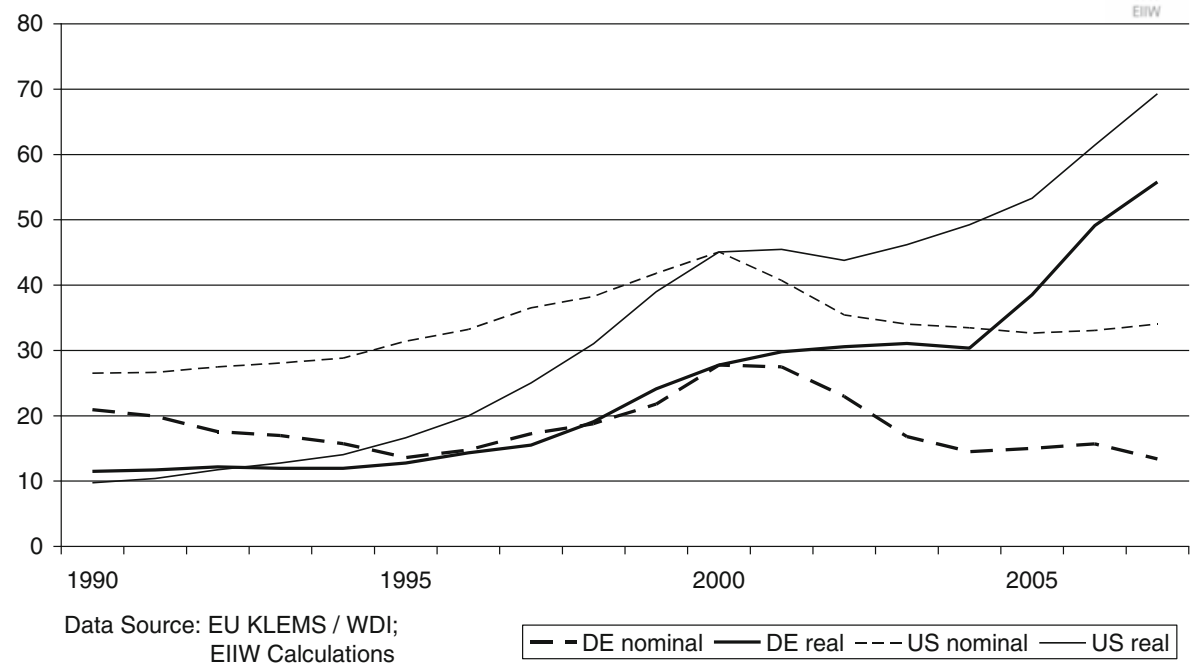

Fig. 5 ICT capital investment in $\%$ of GDP (base year 2000) 


\section{Results}

Following from the development that has been described above - especially from the plotted development trends - it becomes clear that with the base year for the price levels set to 1990, the ICT investment ratios mostly show a trend of growing divergence. Nevertheless the investment ratio itself in none of the five countries is diminishing but increasing.

In detail it can be seen that the US strengthens its lead market position in the ICT sector, while Germany catches up with the UK, which in 2007 still has a lead on Germany, though this lead is steadily diminishing. Interestingly enough in the years from 2003 to 2005 Germany even lagged behind Spain, but in 2006 managed to jump ahead again. An explanation for this might be found in aftermath of the Dotcom crisis. Finally, it is Italy that gets the last place. Hence there should be considerable room for catching up and additional ICT investment that in turn should stimulate economic growth-Oxford Economics (2012) has argued that for both Italy and Spain a higher ICT investment level per capita, similar to the US level, would, within less than a decade, lead to extra aggregate output growth of $7 \%$.

Returning to the theoretical link between ICT investments and GDP that have been introduced in the second section, it can be said that in all countries the coefficient

$$
\frac{(1+\varphi)}{1-\alpha \mathrm{I}_{\mathrm{t}}^{\mathrm{ICT}-\text { stock }}}
$$

is steadily increasing - especially in the case of the US. A rise of the coefficient as a whole might be due to a rise in the ICT stock which lowers the denominator, signifying the rise of network effects through the enhanced ICT infrastructure. This would signify that the network effects of ICT might be decreasing. On the other hand $\varphi$ can be increasing which would indicate that in the US ICTs plays a steadily increasing role in different industries aside from the ICT sector itself.

If the US is having a steeper development of ICT investments than the other countries this implies that also in the US the network effects are increasing much faster than in other countries and industries have more potential to develop other commodities that use ICTs in their development and realization. Therefore, in some part a self-contained development trend is present, indicating that the observed developments will not be a random short-term trend but a sustainable development trend.

\section{Imputed internet value-added from households}

Many users of the internet are surfing at home or when travelling. What type of activity is this internet surfing of private households? To a large extent it stands for consumption, but often there is also value-added since certain internet activities actively involve the user to provide certain services; e.g. if a certain individual goes to a travel agency and books a vacation trip the travel agency will charge a certain fee for this service, and this fee-reflecting wages or capital costs — are included as value-added in the System of National Accounts. If, however, the individual decides to conduct some screening of vacation options at home on the internet and then proceeds by typing in relevant data for vacation $\mathrm{X}$ booked on an internet platform the individual is effectively contributing to 
value-added - but this activity is not recorded in the official statistics. Indeed, there are many activities where individuals act as "prosumers" (a hybrid role as a consumer who is also active as a producer) in the digital world: there is both an element of consumption and an element of production in certain activities and the problem is that the production activities of million of users are not covered by the official statistics so that the economic relevance of information \& communication technology and the internet, respectively, are not fully understood. Moreover, with increasing online learning - part of which is free online learning - modern digital societies create new platforms of digital value-added and human capital formation, but again, there is very scant statistical coverage of such activities and knowledge about successful learning activities in the field of Massive Open Online Courses is not generally available. In Germany, the Hasso Plattner Institute - a computer science institution at the University of Potsdam - has offered five online courses; roughly 50000 individuals signed up for these courses, $17 \%$ successfully passed the relevant examinations (HPI, 2013). Here we see important new digital dynamics. If one assumes that a certain percentage of the online time of private households represents value-added the official GDP figures have to be revised upwards; the monetization of one hour of online value-added can use the opportunity cost of time, namely the average GDP per hour (from the official statistics).

Tables 3 and 4, based on different sources (comscore, 2012a, 2012b, 2013a, 2013b, 2013c; World Bank, 2013) for the average times internet users spend online, how much additional GDP they could have generated if it is assumed that part of the time budget is value-adding; the growing role of digital prosumers for value-added in the internet should be considered and $10 \%-20 \%$ of household's time budget seems to be a realistic order of magnitude. Using the relevant value-adding internet time budget of private households and multiplying with average labor productivity — based on the official GDP data-indeed is an easy way to get an estimation for the output value of private household's internet activities. With households using more sophisticated software and mobile internet density still increasing in most countries one should expect considerable medium term expansion potentials for digital GDP created by private households. While both tables inherently present the same contents it can be seen that there is a significant gap between the numbers in both cases. These discrepancies however seem to be systemic in nature and therefore they are not due to inconsistencies across countries but due to different methods of data collection. In the tables the modest estimate of $10 \%$ of private household's online time being used for value-added seems to be adequate. This already gives rise to considerable extra GDP which so far is, of course, not covered by the System of National Accounts.

It is interesting to consider actual user profiles as reported for example by Experian Marketing Services; it shows that assuming a high internet usage as being unproductive is a rather implausible assumption - with social networking standing for more than a quarter of online time and shopping and entertainment for another quarter. Pure business usage is listed as a mere $5 \%$. Therefore it is more adequate to assume the unproductive share of internet usage to be in the range of 20-50\%. From a different perspective it can be said that every $10 \%$ of internet usage that is spent productively during internet usage generates an additional $1.3-4.6 \%$ of GDP that is not part of the official GDP statistics and should be considered as well. If the internet value-added time share were $20 \%$ we would already come close to $10 \%$ of GDP in some countries. Here further research is needed on the time allocation of private households: As these invest more in software and advanced 
Table 3 Opportunity costs of internet usage (in billion US \$) (based on comScore internet usage data)

\begin{tabular}{|c|c|c|c|c|}
\hline 2012 & $\begin{array}{l}\text { Opportunity costs } \\
\text { (100\% use) }\end{array}$ & $\begin{array}{l}\text { Share of GDP } \\
\text { ( } 20 \% \text { use) }\end{array}$ & $\begin{array}{l}\text { Share of GDP } \\
\text { (10\% use) }\end{array}$ & $\begin{array}{l}\text { Share of GDP } \\
(50 \% \text { use) }\end{array}$ \\
\hline US & 3688.03 & 2.35 & 4.70 & 11.76 \\
\hline Japan & 532.52 & 0.89 & 1.79 & 4.47 \\
\hline UK & 505.10 & 2.07 & 4.15 & 10.37 \\
\hline Germany & 447.87 & 1.32 & 2.63 & 6.59 \\
\hline Canada & 391.61 & 2.15 & 4.30 & 10.75 \\
\hline France & 376.76 & 1.44 & 2.88 & 7.21 \\
\hline China & 315.03 & 0.38 & 0.77 & 1.91 \\
\hline South Korea & 177.18 & 1.57 & 3.14 & 7.84 \\
\hline Brazil & 166.74 & 0.74 & 1.48 & 3.70 \\
\hline Netherlands & 166.61 & 2.16 & 4.32 & 10.79 \\
\hline Russia & 163.79 & 0.81 & 1.63 & 4.06 \\
\hline Spain & 140.65 & 1.04 & 2.09 & 5.21 \\
\hline Italy & 130.38 & 0.65 & 1.30 & 3.24 \\
\hline Norway & 81.32 & 1.63 & 3.25 & 8.13 \\
\hline Sweden & 69.20 & 1.32 & 2.63 & 6.58 \\
\hline Switzerland & 58.93 & 0.93 & 1.86 & 4.66 \\
\hline Belgium & 56.02 & 1.16 & 2.31 & 5.79 \\
\hline Turkey & 52.93 & 0.67 & 1.34 & 3.35 \\
\hline Poland & 52.33 & 1.07 & 2.14 & 5.34 \\
\hline Denmark & 41.36 & 1.32 & 2.63 & 6.59 \\
\hline Finland & 39.27 & 1.57 & 3.14 & 7.85 \\
\hline Austria & 28.35 & 0.71 & 1.42 & 3.54 \\
\hline Ireland & 21.40 & 1.02 & 2.04 & 5.09 \\
\hline Singapore & 17.14 & 0.62 & 1.25 & 3.12 \\
\hline Malaysia & 16.55 & 0.54 & 1.09 & 2.72 \\
\hline Portugal & 16.54 & 0.78 & 1.56 & 3.90 \\
\hline India & 16.35 & 0.09 & 0.18 & 0.44 \\
\hline Thailand & 13.82 & 0.38 & 0.76 & 1.89 \\
\hline Indonesia & 9.90 & 0.11 & 0.23 & 0.56 \\
\hline Philippines & 7.82 & 0.31 & 0.63 & 1.56 \\
\hline Vietnam & 7.19 & 0.51 & 1.01 & 2.53 \\
\hline
\end{tabular}

Source: comScore, World Bank, ITU, OECD, national statistical offices own calculations

hardware over time while engaging also in more digital networking — raising "domestic ICT productivity" - one might assume that internet-based value-added of private households in many countries could still rise and one cannot rule out that even up to $20 \%$ of user time of households in some countries is hidden digital value-added. If cities offer free WIFI (as is happening in some countries) this might be considered to be stimulating the expansion of ICT networks, however, it could also be an incentive for students and pupils to learn faster and thereby become more productive in the use of the existing regional or local ICT capital stock. 
Table 4 Opportunity costs of internet usage (in billion US \$) (based on internetworldstats internet usage data)

\begin{tabular}{lllcc}
\hline & $\begin{array}{l}\text { Opportunity costs } \\
(100 \% \text { use })\end{array}$ & $\begin{array}{l}\text { Share of GDP } \\
(10 \% \text { use })\end{array}$ & $\begin{array}{l}\text { Share of GDP } \\
(20 \% \text { use })\end{array}$ & $\begin{array}{l}\text { Share of GDP } \\
(50 \% \text { use })\end{array}$ \\
\hline US & 7813.31 & 5.21 & 10.42 & 26.06 \\
Germany & 1658.55 & 4.60 & 9.20 & 23.01 \\
UK & 1292.36 & 5.32 & 10.64 & 26.60 \\
France & 1062.05 & 3.83 & 7.65 & 19.13 \\
Italy & 703.16 & 3.20 & 6.40 & 16.01 \\
Spain & 487.10 & 3.30 & 6.59 & 16.48 \\
New Zealand & 89.97 & 5.52 & 11.04 & 27.60 \\
\hline
\end{tabular}

Source: Internetworldstats, ITU, World Bank, OECD, national statistics own calculations

\section{Policy conclusions}

The analysis presented has shown that true real ICT investment-GDP share are higher than indicated by official statistics; and that there is a considerable share of internet value-added that, so far, is not covered at all by the System of National Accounts. Hence the role of ICT for economic growth is clearly underestimated by official statistics. The positive external effects of ICT research and development and ICT innovations, respectively, are most likely underestimated by policy makers and hence the promotion of ICT innovation is sub-optimal. It also is interesting to consider the role of the adaptation cost of ICT expansion. Since the internet is a truly global digital market, one should also consider the role of an international digital growth spillover. From the perspective of the EU countries an insufficient knowledge about cross-country spillovers leads us to expect that digital $\mathrm{R} \& \mathrm{D}$ promotion is inadequate.

It will be interesting to analyse the price dynamics of the ICT sector. As long as the relative ICT (investment) price index is falling relative to the price index for capital equipment the share of ICT investment in total investment is likely to increase and this in turn implies that the ICT capital stock relative to the total capital stock will rise. It would be interesting to analyse the implications from such structural changes - this could include a rise of the output elasticity of capital which in turn has many important implications; e.g. the revenuemaximizing income tax rate in a growth model can be shown to be equal to 1- $\beta$ (Welfens 2013 , p. 57) so that a rise of $\beta$ could bring about pressure for lower income tax rates world wide.

While the analysis here has presented findings for a rather limited range of countries a broader data base could allow a wider coverage in the future. The EU's KLEMS database is quite useful but a broader global data set is needed. To the extent that the World Bank has increasingly emphasized the digital modernization of economies one may expect that member countries of the World Bank will collect broader data, including on the time budget of households on the internet. Survey results for both OECD, and other, countries on the split of the time budget into "digital consumption" and "digital value-added" would also be useful. 


\section{Appendix: economic growth and ICT}

A simple growth model with knowledge and digital progress (Welfens 2013)

Long run economic growth and capital accumulation plus learning costs can be analyzed within a modified growth model. In a modern economy knowledge, (A), is important for production. New knowledge, however, cannot be implemented without training workers at some training cost. Thus savings are not only necessary to finance gross capital formation $\mathrm{dK} / \mathrm{dt}+\delta \mathrm{K}$ ( $\mathrm{K}$ is the capital stock, $\mathrm{t}$ is time and $\delta$ is the capital depreciation rate) but also to upgrade the skills of workers at some cost for training. Let us assume that these are proportionate to real per capita income $y:=\mathrm{Y} / \mathrm{L}$ ( $\mathrm{Y}$ is real GDP, L is labor): Innovation managers who have to train workers in using more advanced technologies will have a salary which is proportionate to the average per capita income, $y$, so that real upgrading costs are a positive function of real per capita income. However, it also is assumed that the costs of labor upgrading is inversely related to knowledge and that the production function can be written as $\mathrm{y}^{\prime}:=\mathrm{Y} /(\mathrm{AL})=\mathrm{k}^{, \beta}$ where $\mathrm{k}^{\prime}:=\mathrm{K} /(\mathrm{AL})$ and $0<\beta<1$. AL is labor in efficiency units. The real upgrading costs $U$ for implementing $\mathrm{dA} / \mathrm{dt}$ with all workers in the whole economy therefore is given by (with $\lambda$ standing for a positive learning curve parameter):

$$
\mathrm{U}=(\mathrm{dA} / \mathrm{dt}) \lambda \mathrm{Ly} / \mathrm{A}=(\mathrm{dA} / \mathrm{dt}) \lambda \mathrm{Lk}^{, \beta}
$$

In an open economy with a balanced government budget and a balanced current account the equilibrium condition for the goods market reads:

$$
\mathrm{S}=\mathrm{dK} / \mathrm{dt}+\delta \mathrm{K}+(\mathrm{dA} / \mathrm{dt}) \lambda \mathrm{Lk}^{, \beta}
$$

Dividing by AL and considering that $\mathrm{dk}^{\prime} / \mathrm{dt}=(\mathrm{dK} / \mathrm{dt}) /(\mathrm{AL})-(\mathrm{a}+\mathrm{n}) \mathrm{k}^{\prime}-$ with a and $\mathrm{n}$ denoting the growth rate of knowledge and labor, respectively - we can write:

$$
\mathrm{S} /(\mathrm{AL})=\mathrm{dk}^{\prime} / \mathrm{dt}+(\mathrm{a}+\mathrm{n}+\delta) \mathrm{k}^{\prime}+\mathrm{a} \lambda \mathrm{k}^{, \beta}
$$

By assumption savings $\mathrm{S}=\mathrm{s}(1-\tau) \mathrm{Y}$ where $\mathrm{Y}$ is real income, $\tau$ the income tax rate and $0<\mathrm{s}<1$ ( $\mathrm{s}$ is the savings rate) so that we have a simply savings function $\mathrm{S} /(\mathrm{AL})=\mathrm{s}(1-\tau) \mathrm{k}^{\prime}$. Hence the differential equation for $\mathrm{dk}^{\prime} / \mathrm{dt}$ reads:

$$
\mathrm{dk}^{\prime} / \mathrm{dt}=(\mathrm{s}(1-\tau)-\mathrm{a} \lambda) \mathrm{k}^{, \beta}-(\mathrm{a}+\mathrm{n}+\delta) \mathrm{k}^{\prime}
$$

The steady state (\#) solution for k'\# therefore is

$$
\mathrm{k}^{\prime} \#=((\mathrm{s}(1-\tau)-\mathrm{a} \lambda) /(\mathrm{a}+\mathrm{n}+\delta))^{1 /(1-\beta)}
$$

As a parameter restriction it is assumed that $s(1-\tau)>a \lambda$. The learning curve parameter $\lambda$ now reduces the level of the growth path. New learning or innovation technologies relevant for the learning process can reduce the parameter $\lambda$ and the internet is a good example for such a new technology. The steady state for $y^{\prime}$ thus is given by: 


$$
\mathrm{y}^{\prime} \#=((\mathrm{s}(1-\tau)-\mathrm{a} \lambda) /(\mathrm{a}+\mathrm{n}+\delta))^{\beta /(1-\beta)}
$$

The learning curve parameter $\lambda$ will reduce the level of y' and hence the level of the growth path in the steady state. As (with e' standing for the Euler number) $\mathrm{A}(\mathrm{t})=\mathrm{A}_{0} \mathrm{e}^{\text {,at }}$ and $\mathrm{L}(\mathrm{t})=\mathrm{L}_{0} \mathrm{e}^{\text {,nt }}$ the growth rate of output in the steady state is given by $(\mathrm{a}+\mathrm{n})$ and the level of the growth path is determined by the expression

$$
\mathrm{A}_{0} \mathrm{~L}_{0}((\mathrm{~s}(1-\tau)-\mathrm{a} \lambda) /(\mathrm{a}+\mathrm{n}+\delta))^{\beta /(1-\beta)}
$$

Some refinement with the progress function is adequate: Consider a progress function (with $\lambda^{\prime}>0$; the exogenous progress rate is denoted by $a_{0}$ ) where the income tax rate has a negative effect on the progress rate while the export ratio $\mathrm{x}$ and the import ratio $\mathrm{j}$ (parameter $\mu>0 ; \mu^{\prime}>0, *$ for foreign variable) as well as $\mathrm{a}^{*}$ have a positive impact on the growth rate of knowledge

$$
a=a_{0}-\lambda^{\prime} \tau+\lambda^{\prime \prime} x+\mu j+\mu^{\prime} a *
$$

In an empirical implication for countries $\mathrm{i}(\mathrm{i}=1,2 \ldots \mathrm{N}$; with the exception of the US) the variable $a^{*}$ might be proxied by the US progress rate and the total factor progress rate, respectively; an alternative could be to consider the growth rate of international patent of US firms.

It has been implicitly assumed here that all exports and all imports contribute to new knowledge - if only a share of exports and imports, respectively, contribute to new knowledge one could adjust the relevant parameters $\lambda$ " and $\mu$ adequately. Given the definition of $\mathrm{a}:=(\mathrm{dA} / \mathrm{dt}) / \mathrm{A}$ we can write

$$
\mathrm{dA} / \mathrm{dt}=\left(\mathrm{a}_{0}-\lambda^{\prime} \tau+\lambda^{\prime}{ }^{\prime} \mathrm{x}+\mu \mathrm{j}+\mu^{\prime} \mathrm{a} *\right) \mathrm{A}
$$

A more open economy, in the sense of a higher $\mathrm{x}$ and $\mathrm{j}$, respectively, will raise $\mathrm{dA} / \mathrm{dt}$ and hence raise the speed of knowledge accumulation. This also holds true for an increase of $\mathrm{a}^{*}$ which is the foreign progress rate. One may consider the role of foreign direct investment for international technology spillovers. Letting $\alpha^{*}$ denote the share of capital in country 1 owned by investors from country 2 one may replace $\mu^{\prime}$ by $\mu^{\prime \prime} \alpha^{*}$ where $\mu$ " $>0$ : a higher share of foreign ownership of the capital stock which goes along with a more intensified international technology transfer. Note, however, that the equilibrium condition for the goods market has also to be adjusted since savings of private households in country 1 are assumed to be proportionate to gross national income (not to GDP); in addition there is investment of foreign subsidiaries so that one can write $S=s(1-\tau)\left(1-a^{*} \beta\right) Y+s^{\prime}(1-\tau) a^{*} \beta Y$; here $\beta$ is the share of capital income in an economy with competitive goods and labor markets and hence real GDP $=\left(1-\mathrm{a}^{*} \beta\right) \mathrm{Y}$ and $\mathrm{s}^{\prime}$ is the investment ratio of foreign subsidiaries in country 1 . 


$$
\mathrm{dk}^{\prime} / \mathrm{dt}=(\mathrm{s}(1-\tau)-\mathrm{a} \lambda)(1-\mathrm{a} * \beta) \mathrm{k}^{, \beta}+\left(\mathrm{s}^{\prime}(1-\tau)-\mathrm{a} \lambda\right) \mathrm{a} * \beta \mathrm{k}^{, \beta}-(\mathrm{a}+\mathrm{n}+\delta) \mathrm{k}^{\prime}
$$

Hence the steady state solution is given by:

$$
\mathrm{k}^{\prime} \#=\left(\left((\mathrm{s}(1-\tau)-\mathrm{a} \lambda)+\left(\mathrm{s}^{\prime}-\mathrm{s}\right)(1-\tau) \mathrm{a} * \beta\right) /(\mathrm{a}+\mathrm{n}+\delta)\right)^{1 /(1-\beta)}
$$

If $s^{\prime}>$ s cumulated foreign direct investment inflows will raise the level of the growth path. However, looking at the progress function $a=a_{0}-\lambda^{\prime} \tau+\lambda^{\prime \prime} x+\mu j+\mu^{\prime} a^{*}$.

Moreover, one may consider that a share $\Omega(0<\Omega<1)$ of the workers are employed for producing new knowledge. The production function is then $\mathrm{Y}=\mathrm{K}^{\beta}(\mathrm{A}(1-\Omega) \mathrm{L})^{1-\beta}$

The differential equation now reads:

$$
\begin{gathered}
\mathrm{dk}^{\prime} / \mathrm{dt}=(\mathrm{s}(1-\tau)-\mathrm{a} \lambda)(1-\mathrm{a} * \beta)(1-\Omega)^{1-\beta} \mathrm{k}^{, \beta}+\left(\mathrm{s}^{\prime}(1-\tau)-\mathrm{a} \lambda\right)(1-\Omega)^{1-\beta} \mathrm{a} * \beta \mathrm{k}^{, \beta} \\
-(\mathrm{a}+\mathrm{n}+\delta) \mathrm{k}^{\prime}
\end{gathered}
$$

The parameter $\Omega$ has a negative impact on the level of the growth rate; however, one has to further consider the role of $\Omega$ in the progress function. The knowledge production function is assumed to be given (with a positive parameter $\Omega$ ') by

$$
\mathrm{dA} / \mathrm{dt}=\left(\mathrm{a}_{0}-\lambda^{\prime} \tau+\lambda^{\prime \prime} \mathrm{x}+\mu \mathrm{j}+\mu^{\prime} \mathrm{a} *+\Omega^{\prime} \Omega\right) \mathrm{A}
$$

Hence the growth rate $\mathrm{d} \ln \mathrm{A} / \mathrm{dt}$ is given by:

$$
\mathrm{a}=\mathrm{a}_{0}-\lambda^{\prime} \tau+\lambda^{\prime}{ }^{\prime} \mathrm{x}+\mu \mathrm{j}+\mu^{\prime} \mathrm{a} *+\Omega^{\prime} \Omega
$$

The parameter $\Omega$ has a positive effect on the trend growth path in the steady state and this effect will clearly dominate in the very long run the negative impact on the level of the growth path. If the efficiency of researchers with respect to the progress rate is rising - indicated by a higher $\Omega$ '- the trend growth rate is raised. The expansion of the ICT sector might indeed bring about such a rise of the parameter $\Omega$ '. A true endogenous growth model would have to explain the parameter $\Omega$ on the basis of companies' optimization decisions and some relative price, respectively; but this can be left for further research.

The main impact of ICT on economic growth from an analytical perspective in a simple enhanced quasi-neoclassical growth model comes from four elements

ICT can increase trade, the export intensity and the import intensity, respectively (Jungmittag and Welfens 2009).

ICT could reduce the learning costs (see the parameter $\lambda$ )

ICT could reinforce the international innovation spillover effect - the typical finding in the literature that innovation spillovers have a rather limited radius (about $300 \mathrm{~km}$ or so is relevant here, however in the internet distance should play a more limited role for the creation of innovations and for the diffusion and spillover processes.

Innovators can have a higher impact on the progress rate since digital $R \& D$ is associated with efficiency gains in innovation. 


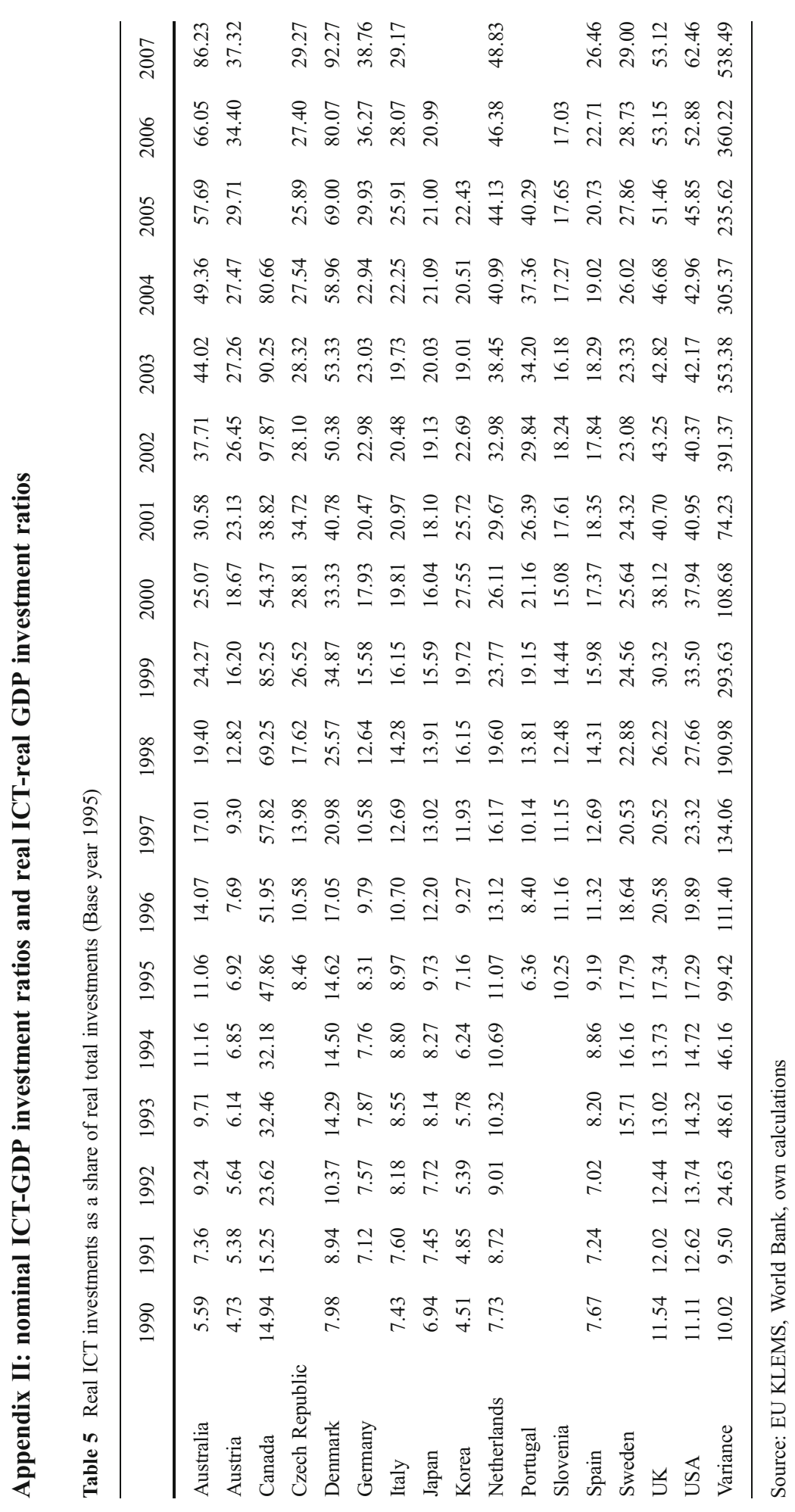




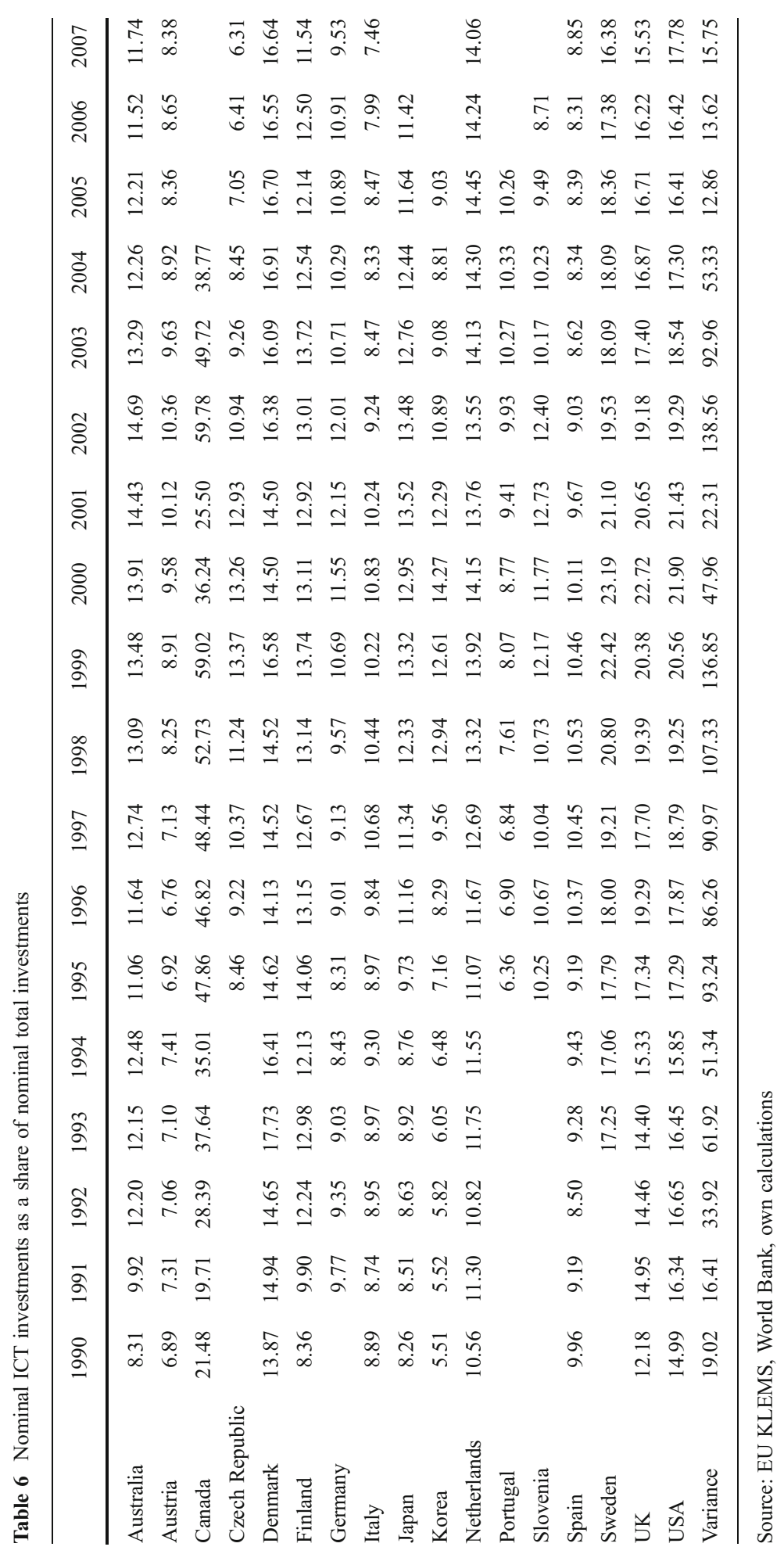




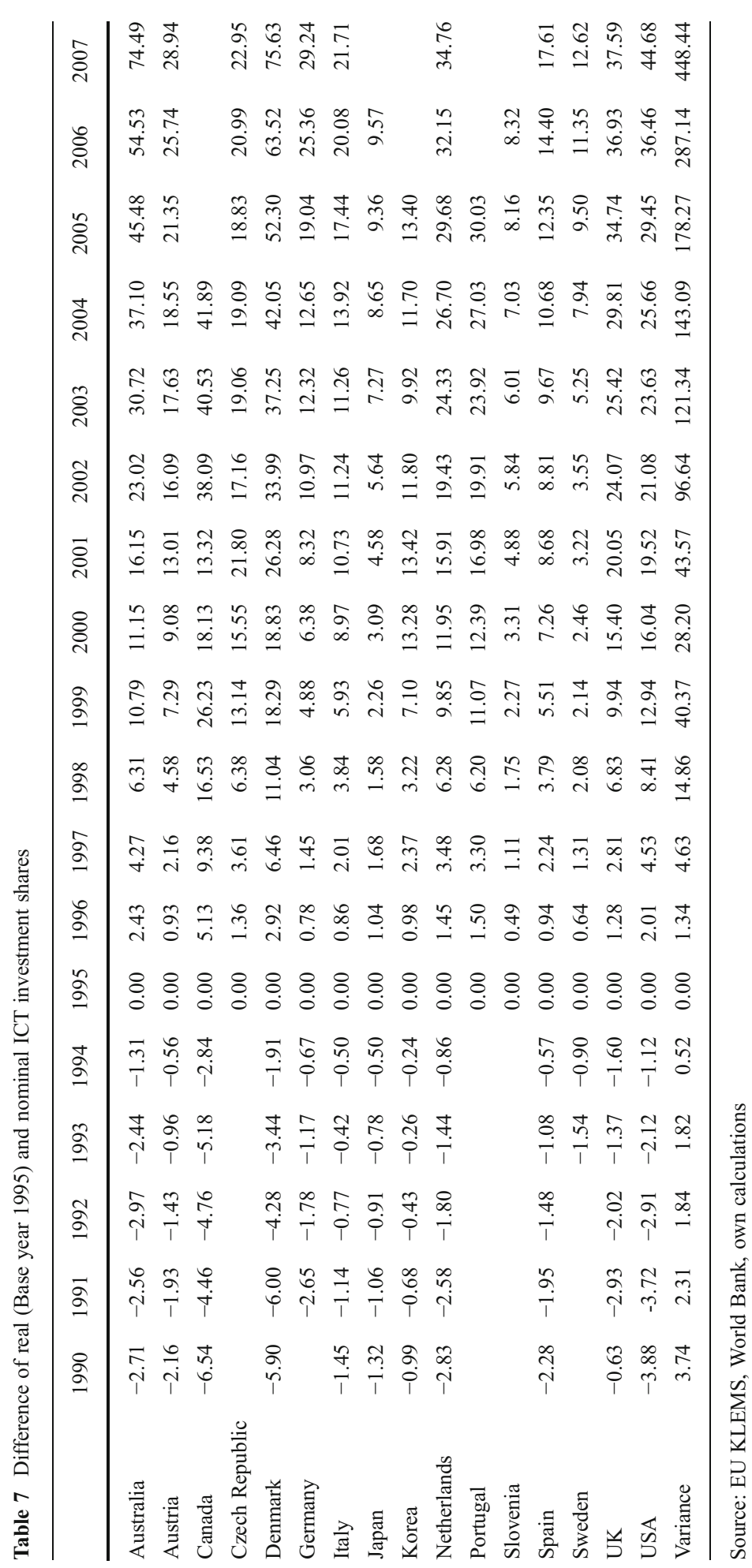


Table 8 Internet usage frequency

2011 Several Once 6 days 5 days 4 days 3 days 2 days Once Less Never times a day a day a week a week a week a week a week a week often

\begin{tabular}{|c|c|c|c|c|c|c|c|c|c|c|}
\hline Portugal & 52.9 & 14.7 & 5 & 6.7 & 3.4 & 1.7 & 1.9 & 2.5 & 4.6 & 6.4 \\
\hline Denmark & 42.1 & 8.2 & 1.7 & 7.3 & 3 & 3.3 & 3.1 & 4.3 & 8.5 & 18.6 \\
\hline South Korea & 41.1 & 13.5 & 3.3 & 5.3 & 3.3 & 3.6 & 3.5 & 4.7 & 6.5 & 15.2 \\
\hline Switzerland & 40.3 & 9.4 & 2.2 & 6.9 & 3.2 & 5.1 & 3.1 & 4.7 & 7 & 18 \\
\hline Norway & 39.8 & 8.6 & 1.9 & 9.9 & 4.9 & 5.5 & 3.3 & 6.3 & 7.6 & 12.1 \\
\hline Estonia & 38.5 & 10.1 & 1.7 & 11 & 2.7 & 2.9 & 2.6 & 3.7 & 9.7 & 17.1 \\
\hline Sweden & 38.2 & 9.7 & 2 & 8.8 & 4.3 & 4.3 & 4.5 & 6.1 & 9.7 & 12.3 \\
\hline China & 37.8 & 13.7 & 3.6 & 9.5 & 3.8 & 6 & 6 & 4.4 & 6 & 9 \\
\hline Luxembourg & 36.4 & 8 & 2.5 & 7.5 & 2.9 & 5.7 & 2.7 & 6.4 & 6.4 & 21.5 \\
\hline Italy & 33.7 & 17.7 & 4.1 & 7.6 & 3.7 & 2.8 & 3.1 & 4.8 & 6 & 16.6 \\
\hline Russia & 33.2 & 13.7 & 5.2 & 5.8 & 3.3 & 5.3 & 4.5 & 6 & 12.4 & 10.6 \\
\hline Slovakia & 30.5 & 13.1 & 3.9 & 9.9 & 4.3 & 4.3 & 5 & 7.3 & 9.4 & 12.4 \\
\hline USA & 30.4 & 11.7 & 2.4 & 8.2 & 3.5 & 3.3 & 3 & 4.7 & 9 & 23.9 \\
\hline Czech Republic & 29.7 & 13.2 & 1.9 & 6 & 3.4 & 3.4 & 3.6 & 6.4 & 11.9 & 20.7 \\
\hline Turkey & 29.5 & 17.1 & 12.5 & 6.4 & 2.6 & 2.8 & 5 & 3 & 6.7 & 14.4 \\
\hline Greece & 29.3 & 18.7 & 4.7 & 10.4 & 7.5 & 2.5 & 3.1 & 5.4 & 9 & 9.4 \\
\hline Poland & 29.3 & 13.5 & 3 & 10.1 & 3.7 & 5.3 & 3.3 & 5.8 & 10.2 & 15.8 \\
\hline Finland & 27.9 & 7.3 & 1.3 & 14.4 & 4.5 & 4.9 & 2.9 & 5.7 & 15.7 & 15.6 \\
\hline Germany & 26.8 & 7.8 & 2.6 & 11.5 & 4.5 & 4.5 & 3.6 & 5.1 & 10.4 & 23.3 \\
\hline Austria & 26.5 & 15.1 & 3.2 & 5.8 & 3 & 4.9 & 3.6 & 5.6 & 11.2 & 21.1 \\
\hline France & 25.9 & 8 & 2.8 & 3.7 & 3.8 & 3.9 & 3.5 & 3.3 & 9.2 & 35.7 \\
\hline Brazil & 25.5 & 17.8 & 6 & 4.7 & 1.8 & 3.4 & 4.8 & 4.7 & 4.4 & 26.9 \\
\hline Spain & 23.9 & 14.1 & 3.7 & 8.7 & 6.6 & 3.9 & 4.6 & 3.4 & 10.3 & 20.9 \\
\hline Ireland & 22.3 & 16.3 & 3.7 & 7 & 3.2 & 6.7 & 5.7 & 7.8 & 10.1 & 17.2 \\
\hline Belgium & 22.2 & 11.1 & 1.9 & 6.8 & 3.4 & 4.4 & 4.4 & 4.8 & 9.9 & 31.1 \\
\hline United Kingdom & 21.7 & 10.6 & 3.4 & 7.4 & 4.4 & 4.4 & 4.5 & 3.9 & 12.4 & 27.3 \\
\hline Japan & 21.3 & 6.9 & 2.1 & 4.6 & 2.9 & 2.9 & 3.1 & 3.2 & 8 & 44.9 \\
\hline New Zealand & 19.1 & 10.3 & 2.5 & 7.8 & 4.8 & 4.4 & 5.5 & 6.5 & 11.4 & 27.8 \\
\hline Netherlands & 18.1 & 7 & 2.5 & 7.8 & 3.9 & 7.5 & 5.1 & 5.9 & 9.8 & 32.4 \\
\hline India & 13.2 & 19.7 & 7.8 & 5.3 & 5.7 & 8.8 & 8.6 & 7.9 & 4.9 & 18.1 \\
\hline Hungary & 10.8 & 7 & 1.5 & 2.5 & 3.4 & 2.5 & 2.2 & 2.5 & 11.9 & 55.6 \\
\hline
\end{tabular}

Source: Infratest

\section{References}

Bazzazan F (2009) The economic importance of ICT in Iran input-output approach. Paper Presented in 2009 International Conference of Information and Financial Engineering

Colecchia A, Schreyer P (2002) ICT investment and economic growth in the 1990s: is the US a unique case? A comparative study of nine OECD countries. Rev Econ Dyn 5-2:408-442

Heng TM, Thangavelu SM (2010) Singapore information sector: a study using input-output tables. IPS Working Papers No. 18 
HPI (2013) URL: http://www.hpi.uni-potsdam.de/willkommen.html

Jungmittag A, Welfens PJJ (2009) Liberalization of EU telecommunications and trade: theory, gravity equation analysis and policy implications. IEEP 6-1:23-39

Jorgenson DW, Stiroh KJ (2000) Raising the speed limit: US economic growth in the information age. OECD economics department working papers, no. 261

Kelly T, Minges M (2012) Information and communications for development 2012: maximizing mobile. Washington DC

Narayana MR (2005) ICT sector and regional economic development: evidence from Karnataka State. Paper Presented in ISEC-Cornell University Conference on Development in Karnataka: A MultiDisciplinary Perspective, 10-12 June 2005 in Bangalore

OECD (2007) Information economy - sector definitions based on the International Standard Industry Classification (ISIC 4). Paris

OECD (2009) Information economy product definitions based on the central product classification (Version 2), Paris

OECD (2012) Internet economy outlook. Paris

Oxford ECONOMICS (2012) Capturing the ICT dividend, Oxford (for AT\&T)

Qiang CZ, Yamamichi M, Hausman V, Miller R, Altman D (2012) Mobile applications for the health sector. Washington DC

Qiang CZ, Kuek CS, Dymond A, Esselaar S (2012a) Mobile applications for agriculture and rural development. Washington DC

Rohman, I.K. (2012), The globalization and stagnation of the ICT sectors in European countries: An input output analysis. Telecommun Policy doi:10.1016/j.telpol.2012.05.001

Seo H, Lee Y, Oh J (2009) Does ICT investment widen the growth gap? Telecommun Policy 33:422-431

Singh R, Raja S (2010) Convergence in information and communication technology: strategic and regulatory considerations. Washington DC

Sudan R, Ayers S, Dongier P, Kunigami AM, Qiang CZ (2010) The global opportunity in IT-based services: assessing and enhancing country competitiveness. Washington DC

Venturini F (2009) The long-run impact of ICT. Empir Econ 37:497-515

Welfens PJJ (2013) Social security and economic globalization. Springer, Heidelberg

World Bank (2012) ICT for greater development impact: sector strategy. Washington DC

Yamamichi M (2012) The role of mobile-enabled social media in social development. Washington DC

Youngman R (2010) ICT solutions for energy efficiency. Washington DC

\section{Data References}

comScore (2012a) Canada digital future in focus comScore (2012b) Canada digital future in focus comScore (2013a) Europe digital future in focus comScore (2013b) Belgium digital future in focus comScore (2013c) Southeast Asia digital future in focus EU KLEMS (2009) Growth and productivity accounts World Bank (2013) World development indicators 